
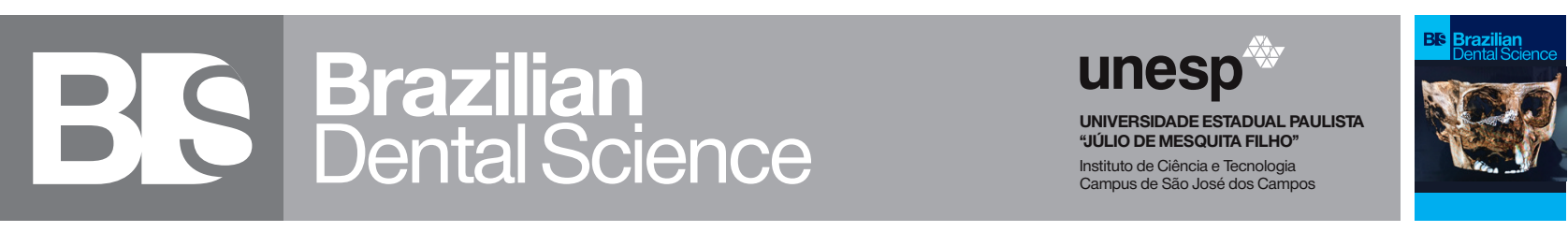

\title{
Microtensile Bond Strength and Failure Type Analysis of Self- Etch Adhesive Systems on Superficial and Deep Dentin After Long-term Water Storage
}

Análise de resistência de adesão à microtração e tipo de falha de sistemas adesivos autocondicionantes em dentina superficial e profunda após armazenamento longitudinal em água

Pinar CEVIK ${ }^{1}$, Arzu Zeynep YILDIRIM² ${ }^{2}$ Zafer ARTVIN ${ }^{3}$, Mutlu ÖZCAN ${ }^{4}$

1 - Associate Professor, Gazi University Faculty of Dentistry - Department of Prosthodontics - Ankara - Turkey.

2 - Associate Professor, Gazi University Faculty of Dentistry - Department of Prosthodontics - Ankara - Turkey.

3 - Research Scientist, Middle East Technical University - Department of Micro and Nanotechnology - Ankara - Turkey

4 - Professor, University of Zurich - Center for Dental and Oral Medicine - Division of Dental Biomaterials - Zurich - Switzerland.

\section{ABSTRACT}

Objective: The aim of this study was to evaluate and compare the microtensile bond strengths of four current adhesive materials that contain different monomers at deep and superficial dentin. Material and Methods: Forty non-carious human third molars $(n=5)$ were used in the study. Specimens were divided into two main groups according to dentin thickness as superficial and deep dentin. Groups were further divided into four subgroups in terms of the adhesive systems used: Nova Compo B Plus (NCBP), Nova Compo B (NCB), Futurabond M (FB) and Clearfil S3 Bond Plus (CS3). All specimens were bonded to resin composite and stored in 37 ${ }^{\circ} \mathrm{C}$ water for 9 -months. Teeth were sectioned into $3 \times 3 \mathrm{~mm}$ thick beams. Microtensile bond strength test was carried out by using a universal testing device $(1 \mathrm{~mm} / \mathrm{min})$. After fracture, failure types were observed using an optical microscope and the fractured dentin surfaces were observed by a scanning electron microscopy (SEM). One-way ANOVA and Tukey tests were used to compare the adhesive system in each dentin group. An unpaired T-test was used to compare the dentin thickness in each adhesive material. Results: As compared to deep dentin, superficial dentin showed higher $\mu$ TBS values in groups NCBP, FB and CS, as opposed to group NCB. Only NCB revealed higher bond strength at deep dentin layers when compared to superficial dentin. In the superficial dentin group, NCBP showed the highest bond strength value,

\section{RESUMO}

Objetivo: o objetivo deste estudo foi avaliar e comparar a resistência de união à microtração de quatro materiais adesivos atuais que contêm monômeros diferentes na dentina profunda e superficial. Material e Métodos: Quarenta terceiros molares humanos não cariados ( $\mathrm{n}=$ 5) foram usados no estudo. Os espécimes foram divididos em dois grupos principais de acordo com a espessura da dentina em superficial e profunda. Os grupos foram subdivididos em quatro subgrupos quanto aos sistemas adesivos usados: Nova Compo B Plus (NCBP), Nova Compo B (NCB), Futurabond M (FB) e Clearfil S3 Bond Plus (CS3). Todos os espécimes foram aderidos à resina composta e armazenados em água a $37^{\circ} \mathrm{C}$ por 9 meses. Os dentes foram seccionados em palitos de $3 \times 3 \mathrm{~mm}$ de espessura. $O$ teste de microtração foi realizado com o uso de um dispositivo de teste universal ( $1 \mathrm{~mm} / \mathrm{min}$ ). Após a fratura, os tipos de falha foram observados em microscópio óptico e as superfícies de dentina fraturadas por microscopia eletrônica de varredura (MEV). Os testes ANOVA e Tukey um fator foram usados para comparar o sistema adesivo em cada grupo de dentina. Um teste $\mathrm{T}$ não pareado foi usado para comparar a espessura da dentina em cada material adesivo. Resultados: Em comparação com a dentina profunda, a dentina superficial apresentou maiores valores de $\mu \mathrm{TBS}$ nos grupos NCBP, FB e CS, ao contrário do grupo NCB. Apenas NCB revelou maior resistência de união na dentina profunda quando comparada à dentina superficial. No grupo de dentina superficial, NCBP apresentou o maior valor de resistência de união, enquanto NCB apresentou a menor 
while NCB showed the lowest bond strength. In the deep dentin group, while NCB showed the highest bond strength value, NCBP revealed the lowest bond strength value after 9-months storage. While 4-META and 10-MDP monomer combination (NCBP) resulted in the highest bond strength value among the adhesive systems in the superficial dentin group, the GPDMA and 4-META monomer combination (NCB) resulted in the highest bond strength in deep dentin group. Conclusions: Microtensile bond strength performance are affected by both the type of monomer in the adhesive combination and the depth of the dentin.

\section{KEYWORDS}

Adhesive system; dentin thickness; hydrophobic monomer; microtensile bond strength; scanning electron microscopy. resistência de união. No grupo de dentina profunda, enquanto NCB apresentou o valor de resistência de união mais alto, NCBP revelou o valor de resistência de união mais baixo após 9 meses de armazenamento. Enquanto a combinação de monômero 4-META e 10MDP (NCBP) resultou no maior valor de resistência de união entre os sistemas adesivos no grupo de dentina superficial, a combinação de monômero (NCB) resultou na maior força de união no grupo de dentina profunda. Conclusões: O desempenho da resistência de união à microtração é afetado tanto pelo tipo de monômero na combinação adesiva quanto pela profundidade da dentina.

\section{PALAVRAS-CHAVE}

Sistema adesivo; espessura da dentina; monômero hidrofóbico; resistência à microtração; microscopia eletrônica de varredura.

\section{INTRODUCTION}

W ith dentin bonding, the final goal is the achievement of a long-lasting and durable interface with resin bonds which will ultimately protect the restoration from secondary caries $[1,2]$. It is micro-mechanical hybridization that causes adhesion to dentin substrate and this is a process that involves the infiltration of adhesive monomers that are polymerized in-situ within the microporous collagen framework, which has been stripped of minerals $[1,3,4]$.

It is known that single-step -self-etchingadhesives are very hydrophilic even after polymerization. This means that self-etching adhesives can absorb water quickly, which leads to increased solubility as compared to conventional multiple step adhesives $[5,6,7]$. Hydrophilic resin polymers suffer decreased mechanical properties when they absorb water as opposed to dry examples [5,8-11]. This is because water absorption causes polymers to swell up and plasticize and can lead to the three-dimensional polymer chain network being weakened $[10,11]$.
These single-step, self-etching adhesives behave like permeable membranes and allow water to move through them even after polymerization because of their highly hydrophilic nature [12]. When water gets into the adhesive resin it causes the polymers to hydrolyse, which in turn causes their mechanical properties to deteriorate. The excess of water form water blisters inside the adhesive, and phase separation at the adhesive/dentin interface has appeared as new types of bond defects [13-15].

Long-term exposure to water may cause further deterioration in the mechanical properties of adhesive polymers. This could have a detrimental effect on the ability of selfetching adhesives to bond to dentin structure, resulting in increased cohesive failures seen in adhesive resins $[16,17]$. Furthermore, there is a hydrophilic monomer called HEMA, which has a positive effect on adhesion to dentin and whose hydrophobic and hydrophilic ingredients in the adhesive mix are quite miscible. HEMA is added to single-step, self-etching adhesives in various concentrations. A downside is that HEMA does attract water after polymerization 
[10], meaning that the long-term stability of the resin to dentin interface could be weaken by high concentration of HEMA.

Another typical phosphate ester functional monomer in the composition is MDP (10-methacryloyloxyolecyl dihydrogen phosphate). It has been reported that the phosphate group of MDP can potentially interact with hydroxyapatite, resulting in the dentinresin bond being more durable in the long-term $[18,19]$.

It has been reported that the dentin bond strengths of single-step, self-etching adhesives are weakened by long-term water storage $[16,17,20]$. This is accompanied by an increase in the instances of cohesive failures in the adhesive resin [17]. Most single-step, selfetching adhesives are available as single bottles containing all the relevant components: ionic resin monomers, acidic phosphate or carboxylic functional groups, hydrophilic and hydrophobic monomers, water plus organization solvents $[21,22]$. It has also been demonstrated that these adhesive polymers behave like semi-permeable membranes, thus allowing water to cross the adhesive layer even after polymerization [11], with an associated deterioration in mechanical properties $[8,11,23]$. Long-term water storage may cause a negative effect between the singlestep self-etching adhesive and dentin, leading to rapid deterioration [24].

The composition of dentin changes with depth; thus, the effectiveness of adhesives also changes even when the same materials are used in different dentin depth. The other properties of dentin such as being naturally wet combined with positive pulpal pressure also have an adverse effect on how strongly adhesives bond. In addition, they can also lead to unfinished polymerization as well as leaks around the edges and/or phase separation $[25,26]$.

The purpose of this study was to evaluate and compare the microtensile bond strengths of four current adhesive materials that contain different functional monomers to superficial and deep dentin. The null hypothesis was that different adhesive systems containing different monomers and dentin thickness would not affect microtensile bond strength between resin composite and dentin after long-term water storage.

\section{MATERIAL AND METHODS}

\section{Specimen preparation}

The types, brands, chemical formulations and the manufacturer's instructions for the adhesive materials used in the present study are listed in Table I.

Table I - One-step adhesive materials used in the study.

\begin{tabular}{|c|c|c|c|}
\hline Material & Composition & Manufacturer & $\begin{array}{l}\text { Manufacturer's } \\
\text { Instructions }\end{array}$ \\
\hline $\begin{array}{l}\text { Nova Compo } \\
\text { BPlus } \\
\text { (NCBP) } \\
\text { (One-step) }\end{array}$ & $\begin{array}{l}\text { bis-GMA, 2-HEMA, } \\
\text { ethanol, (MDP), } \\
\text { 4-META, silanated } \\
\text { nano silica, dl-Cam- } \\
\text { pherquinone, accele- } \\
\text { rators, initiators, water }\end{array}$ & $\begin{array}{l}\text { Imicryl Inc., Konya, } \\
\text { Turkey }\end{array}$ & $\begin{array}{l}\text { Apply bond for } 20 \mathrm{~s} \text {. } \\
\text { Apply two separate } \\
\text { coats of Nova Compo } \\
\text { B Plus +, scrubbing } \\
\text { the preparation with a } \\
\text { microbrush for } 15 \mathrm{~s} \text { per } \\
\text { coat. Do not light cure } \\
\text { between coats. Disper- } \\
\text { se the bond with dry } \\
\text { air. Light cure for } 10 \mathrm{~s} \text {. }\end{array}$ \\
\hline $\begin{array}{l}\text { Nova Com- } \\
\text { po B } \\
\text { (NCB) } \\
\text { (One-step) }\end{array}$ & $\begin{array}{l}\text { bis-GMA, 2-HEMA, } \\
\text { ethanol, GPDMA, } \\
\text { 4-META, silanated } \\
\text { high dispersed silica, } \\
\text { dl-Campherquinone, } \\
\text { accelerators, initia- } \\
\text { tors, water }\end{array}$ & $\begin{array}{l}\text { Imicryl Inc., Konya, } \\
\text { Turkey }\end{array}$ & $\begin{array}{l}\text { Apply bond for } 20 \mathrm{~s} \text {. } \\
\text { Disperse the bond } \\
\text { with dry air. Light cure } \\
\text { for } 10 \mathrm{~s} \text {. }\end{array}$ \\
\hline $\begin{array}{l}\text { Futurabond M } \\
\text { (FB) } \\
\text { (One-step, one } \\
\text { bottle) }\end{array}$ & $\begin{array}{l}\text { 2-hydoxymethacryla- } \\
\text { te,(UDMA), HEMA, } \\
\text { catalyst, acetone, } \\
\text { nano-sized silica fillers }\end{array}$ & $\begin{array}{l}\text { Voco, GmbH, } \\
\text { Cuxhaven, Ger- } \\
\text { many }\end{array}$ & $\begin{array}{l}\text { Apply bond for } 20 \mathrm{~s} \text {, } \\
\text { dry adhesive layer for } \\
5 \mathrm{~s} \text {, polymerise with } \\
\text { blue light for } 10 \mathrm{~s} \text {. }\end{array}$ \\
\hline $\begin{array}{l}\text { Clearfil S3 } \\
\text { Bond Plus } \\
\text { (CS3) } \\
\text { (One-step) }\end{array}$ & $\begin{array}{l}\text { 10-MDP,Bis-GMA, } \\
\text { HEMA, hydrophobic } \\
\text { and hydrophilic alipha- } \\
\text { tic dimethacrylate, } \\
\text { Sodium fluoride } \\
\text { dl-camphorquinone, } \\
\text { silanated colloidal } \\
\text { silica, ethanol and } \\
\text { water }\end{array}$ & $\begin{array}{l}\text { Kuraray, Noritake } \\
\text { Dental Inc., } \\
\text { Kurashiki, Japan }\end{array}$ & $\begin{array}{l}\text { Apply bond for } 10 \mathrm{~s} \text {; } \\
\text { mild air for } 5 \mathrm{~s} \text {, light-cu- } \\
\text { re for } 10 \mathrm{~s}\end{array}$ \\
\hline
\end{tabular}

Note: Bis-GMA: 2,2-bis(4-(2-hydroxy-3-methacryloylpropoxy))phenylpropane; HEMA: 2-hydroxyethylmethacrylate; GPDMA: Glycerol phosphate dimethacrylate; 10-MDP: 10-methacryloyloxydecyl dihydrogenphosphate; 4-META: 4-methacryloxyethyltrimellitate; UDMA: Urethane dimethacrylate 
Forty non-carious human third molars ( $\mathrm{n}=5$ ) were collected. The teeth were cleansed of debris and tissue remnants with a scaler and stored in a saline solution, and used within two months of extraction. All teeth used in the present study were extracted for reasons unrelated to this project. Written informed consent for research purpose of the extracted teeth was obtained by all donors prior to extraction according to the directives set by the National Federal Council. Ethical guidelines were strictly followed and irreversible anonymization was performed in accordance with State and Federal Law (World Medical Association, Declaration of Helsinki, 2013; Human Research Act, 2015).

The apical parts of the teeth were embedded in a silicon mold up to the level of the cemento-enamel junction using autopolymerizing acrylic resin (Imicryl, Konya, Turkey). The teeth were randomly divided into 8 groups according to adhesive materials and dentin thickness.

The specimens were divided into two main groups ( $\mathrm{n}=20$ per group) according to dentin thickness, initially: 1) Superficial dentin group: The occlusal enamel of the teeth was removed by cutting with a cooled diamond disc in order to create a flat surface in the superficial dentin. 2) Deep dentin group: The coronal section was removed by a cooled diamond disc below the level of the mid-coronal dentin so as to create a flat surface in the deep dentin. Subsequently, the specimens were divided into 4 subgroups ( $n=5$ per group) to be conditioned with one of the following one-step self-etch adhesive materials: Group NCBP (Nova Compo B Plus $\neg$, Imicryl Inc., Konya, Turkey), Group NCB (Nova Compo B, Imicryl), Group FB (Futurabond M, Voco, GmbH, Cuxhaven, Germany) Group CS3 (Clearfil S3 Bond Plus, Kuraray, Noritake Dental Inc., Kurashiki, Japan).
The exposed dentin surfaces in each dentin group were polished with wet 600-grit paper so as to obtain a standardized surface. In deep dentin group, the remaining dentin thickness was also measured after obtaining test sticks to make sure about the getting the deep dentin surface. After rinsing and gently air drying, the specimens the adhesive materials were applied to the dentin surfaces according to manufacturer's instructions. The adhesive materials were light cured for 10 $s$ with a LED light curing unit (Bluephase, Ivoclar Vivadent, Schaan, Liechtenstein). The resin composite (Charisma smart, Shade:A2, Heraeus Kulzer, Germany) measuring 5 $\mathrm{mm}$ in thickness was placed incrementally in two stages using a matrix band system (Hahnenkratt, GmbH, Königsbach-Stein, Germany). Each composite layer was light cured for $40 \mathrm{~s}$ using a LED light curing unit (Bluephase, Ivoclar Vivadent, Schaan, Liechtenstein)

\section{Microtensile bond strength ( $\mu$ TBS) testing}

After being stored in distilled water at $37{ }^{\circ} \mathrm{C}$ in an incubator (Nüve Laboratory Systems, Ankara, Turkey) for nine months the resin-bonded specimens were sectioned perpendicularly with a diamond blade (Isomet, Low Speed Saw, Buehler lake Bluff, IL USA) in order to create serial resin-dentin slabs. Each slab was sectioned into $3 \mathrm{~mm}$ x $3 \mathrm{~mm}$ resin-dentin sticks. An average of two sticks were taken from every tooth. In this study, researchers obtained pure dentin sticks without any deformities from each tooth. Therefore, one stick for each tooth, a total of five resin-dentin sticks per group, was tested in each adhesive resin group. Dentin thickness was also measured prior to testing. In this regard, to categorize the deep dentin group, a manual caliper was used to measure the remaining dentin thickness. Deep dentin groups were categorized while 
the measurement was below $2 \mathrm{~mm}$ from the top layer of the tooth to the pulp chamber. The stickers were then attached to jigs with cyanoacrylate glue (Pattex Instant Glue, Henkel, Germany) and the $\mu$ TBS testing was carried out at a crosshead speed of $1 \mathrm{~mm} /$ min using a universal testing device with a $200 \mathrm{~N}$ compact force gauge (Microtensile Tester, Compact Gauge, 200N, Bisco, Inc, Schaumburg, USA). The $\mu$ TBS test results were calculated in MegaPascals (Mpa) by dividing the force at the time of fracture by the size of the bonded area.

\section{Failure mode and SEM analysis}

Failure types at the fracture sites were observed using an optical microscope (Leica Microsystems, Danaher Corporation, USA). Then the failure modes were classified as follows: Type I: Adhesive failure between the adhesive resin and dentin; Type II: Mixed failure between adhesive resin and dentin with an adhesive remnant on the dentin surface; Type III: Cohesive failure in the resin composite.

Afterwards, the fractured dentin surfaces of the specimen sticks were mounted on aluminum stubs and gold-sputter coated with an $18 \mathrm{~nm}$ thick layer of gold (80\%) / palladium (20\%) then observed using a scanning electron microscopy (SEM) (QUANTA 400F Field Emission SEM, Hillsboro, USA) at $1.2 \mathrm{~nm}$ resolution in the central laboratory of METU (Middle East Technical University). Images were made at $0.2-30 \mathrm{kV}$ at a magnification of $\mathrm{x} 1000$.

\section{Statistical analysis}

Data were analysed using statistical software (SPSS Version 20.0; SPSS Inc., Chicago, IL, USA) program. Statistical significance was determined as $\mathrm{p}<0.05$. Interactions between the dentin groups and the adhesive materials and the effect of dentin thickness and the type of adhesive material on the $\mu$ TBS testing data were analysed using a two-way analysis of variance (ANOVA). Oneway ANOVA and Tukey pairing comparisons were used to compare the adhesive system in each dentin group. An unpaired T-test was used to compare the dentin groups in each adhesive material.

\section{RESULTS}

The results for the microtensile bond strength test in MPa are presented in Table II. The mean $\mu$ TBS values showed significant differences between the adhesive materials ( $\mathrm{p}$ $<0.05$ ). Also, Table III indicates the fracture modes of four one-step adhesive materials.

Table II - Microtensile bond strength values (MPa) of four adhesive material bonded to different dentin thickness.

\begin{tabular}{|c|ccc|}
\hline $\begin{array}{c}\text { Adhesive } \\
\text { material }\end{array}$ & Type I & Type II & Type III \\
\hline NCBP & 80 & 20 & 0 \\
\hline NCB & 0 & 40 & 60 \\
\hline FB & 60 & 40 & 0 \\
\hline CS3 & 0 & 60 & 40 \\
\hline
\end{tabular}


Table III - Fracture modes of four one-step adhesive materials (\%).

\begin{tabular}{|c|c|c|c|c|c|c|c|c|c|}
\hline \multirow[b]{2}{*}{ Bonding agent } & \multicolumn{4}{|c|}{ Superficial dentin } & \multicolumn{5}{|c|}{ Deep dentin } \\
\hline & Mean & $\begin{array}{c}\text { Std. } \\
\text { Deviation }\end{array}$ & Min. & Max. & Mean & $\begin{array}{c}\text { Std. } \\
\text { Deviation }\end{array}$ & Min. & Max. & TEST \# \\
\hline Nova plus & $4.5^{b}$ & 1.7 & 2.5 & 6.7 & $0.8^{\mathrm{a}}$ & 0.4 & 0.3 & 1.6 & $\begin{array}{l}t=4.500 \\
p=0.011\end{array}$ \\
\hline Nova & $2.2^{\mathrm{a}}$ & 0.8 & 1.3 & 3.5 & $4.1^{\mathrm{c}}$ & 2.4 & 1.9 & 8.4 & $\begin{array}{l}t=-1.633 \\
p=0.173\end{array}$ \\
\hline Futurabond M & $3.8^{\mathrm{ab}}$ & 1.1 & 2.4 & 4.9 & $1.4^{\mathrm{ab}}$ & 0.9 & 0.2 & 2.4 & $\begin{array}{l}t=3.718 \\
p=0.621\end{array}$ \\
\hline CS3 Plus & $3.2^{\mathrm{ab}}$ & 1.4 & 1.9 & 4.4 & $3.8^{\mathrm{cb}}$ & 0.6 & 3.2 & 5.0 & $\begin{array}{l}t=-1.200 \\
p=0.500\end{array}$ \\
\hline TEST & \multicolumn{4}{|c|}{$F=3.241 . p=0.050^{*}$} & \multicolumn{5}{|c|}{$F=7.228 . p=0.030^{\star}$} \\
\hline
\end{tabular}

With respect to dentin thickness, when compared to deep dentin superficial dentin showed higher $\mu$ TBS values in groups NCBP, FB and CS, as opposed to group NCB. Only NCB revealed higher bond strengths at deep dentin layers when compared to superficial dentin.

In the superficial dentin group Nova Compo B Plus showed the highest bond strength values, which were statistically different from Nova Compo B but similar to Clearfil S3 Bond Plus and Futurabond M. In the deep dentin group Nova Compo B showed the highest bond strength value, which was statistically different from Nova Compo B Plus and Futurabond M, but similar to Clearfil S3 Bond Plus.

SEM findings indicate that different surface topographies exist at the fracture sites of the specimens in the various dentin and adhesive material groups Figure 1a, 1b, 1c and 1d indicates the SEM images of groups NCBP, $\mathrm{NCB}, \mathrm{FB}$ and CS3, respectively at the superficial dentin surface after fracture. Also, Figure 2a, $2 \mathrm{~b}, 2 \mathrm{c}$ and $2 \mathrm{~d}$ indicates SEM images of NCBP, $\mathrm{NCB}, \mathrm{FB}$ and CS3, respectively at the deep dentin surface after fracture. While the SEM findings of NCBP in superficial dentin (Figure 1a) support the fact that there are strong ionic bonds between adhesive resin and dentin structure, the SEM findings of the NCBP that demonstrated the lowest bond strength with deep dentin surfaces indicate the presence of a thin hybrid layer with concentrated gaps (Figure 2a). In the NCB that demonstrated the lowest bond strength with superficial dentin some gaps at the resin-dentin interface can be seen (Figure 1b). However, in the NCB that demonstrated the highest bond strength in the deep dentin group, a firmly polymerized hybrid layer can be observed at the fracture site (Figure 2b). 


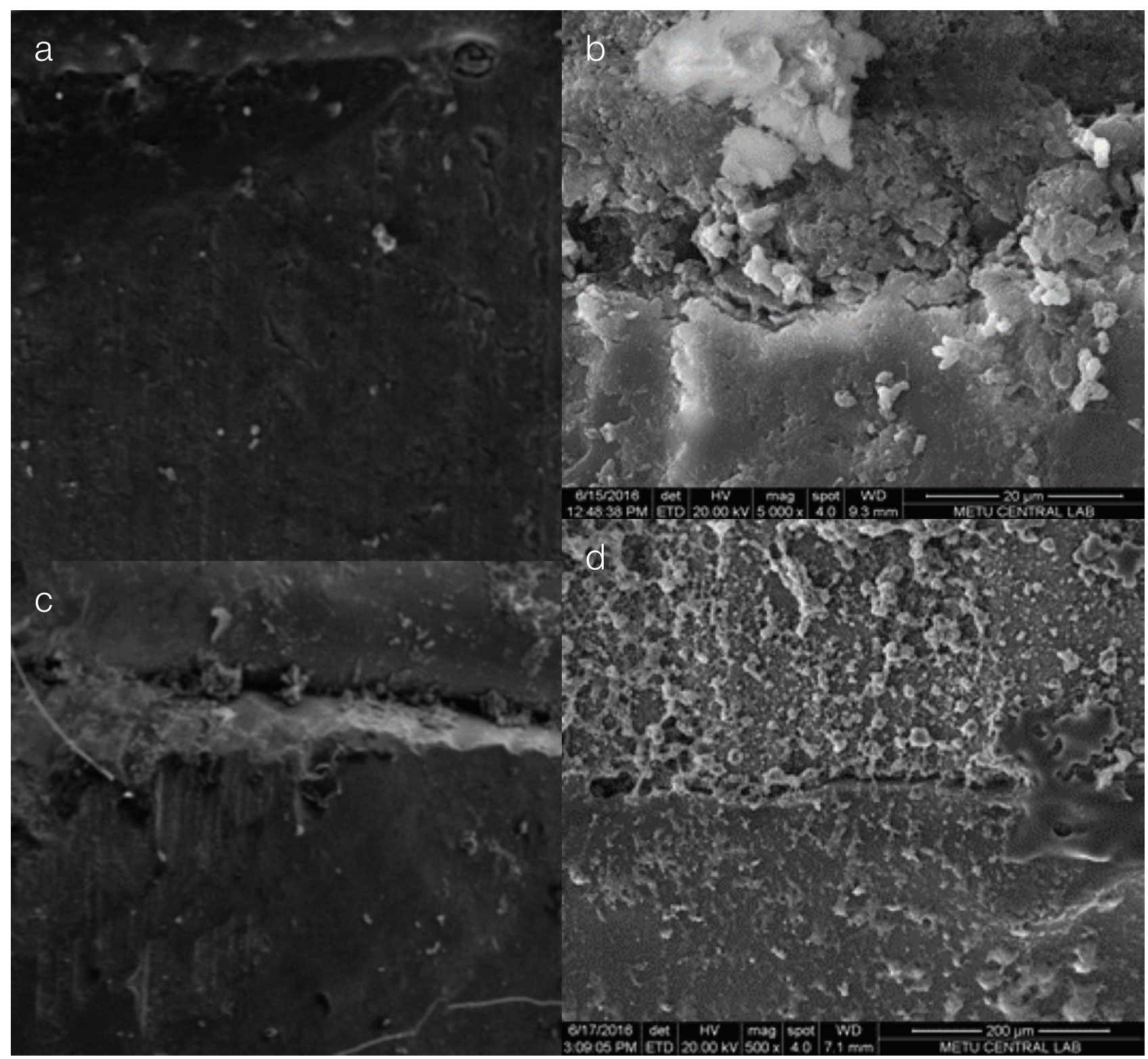

Figures 1a-d - SEM image of a) NCBP, b) NCB, c) FB, d) CS3 at superficial dentin after failure at 1000x magnification. 


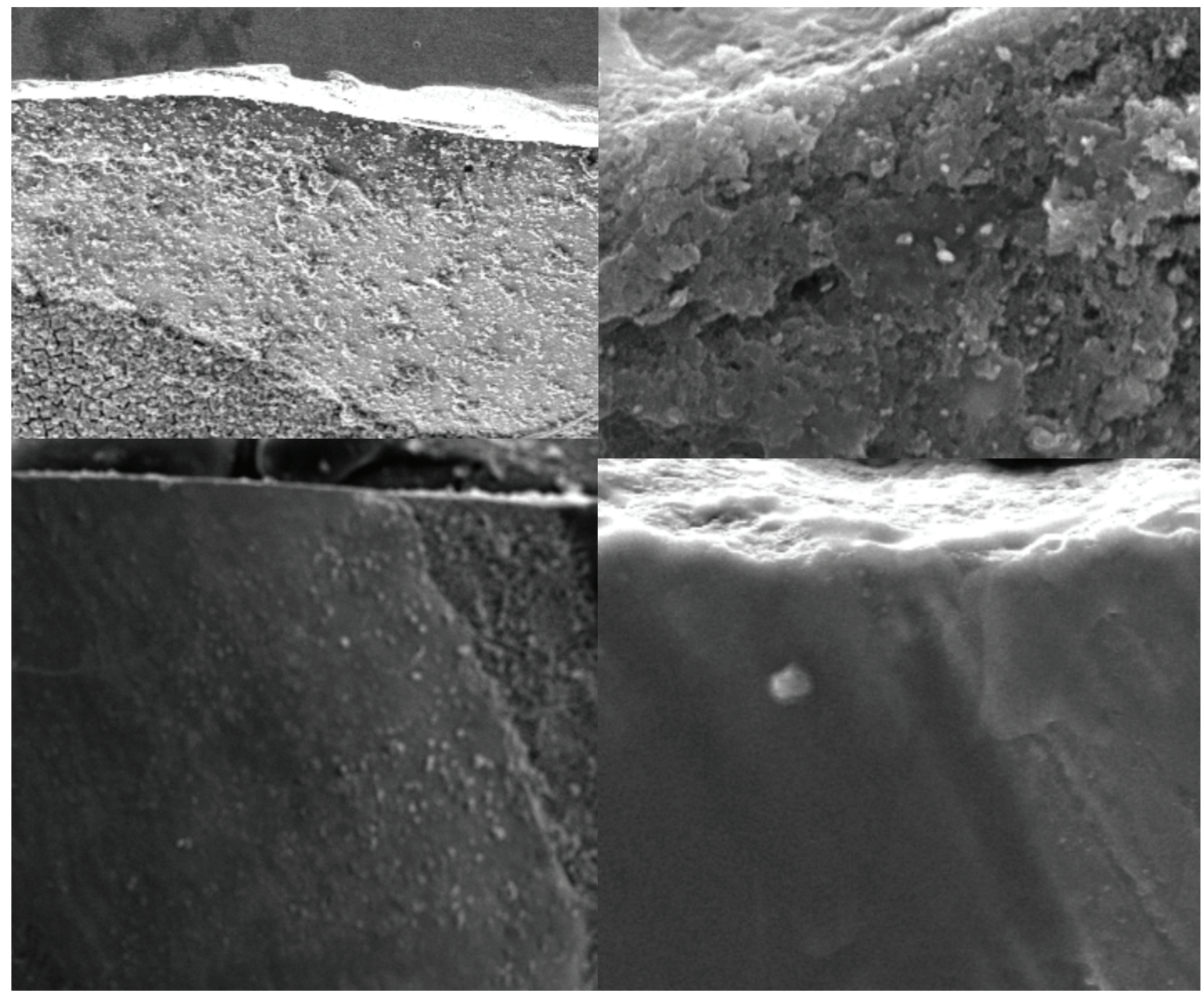

Figures 2a-d - SEM image of a) NCBP, b) NCB, c) FB, d) CS3 at deep dentin after failure at 1000x magnification.

\section{DISCUSSION}

In this study, both dentin thickness and different adhesive systems containing different functional monomers were found to have effects on $\mu$ TBS between resin composite and dentin. The null hypothesis was rejected in this study as the $\mu$ TBS values were affected by the both type of the adhesive systems and dentin thickness after nine months of water storage.

In the present study, one dentin sticks from each tooth, five sticks per group, were studied. As suggested by Roulet et al. [27], sticks that failed prior to microtensile testing were excluded from statistical analysis [28].
One major issue on debate in the current literature is the number of the micro specimens which prepared from required number of individual teeth to be statistically sound. A proper method to handle this problem is to use each tooth in its own control group. It would be the best way to know which micro specimen comes from which tooth.[29] It is generally accepted that using a minimum of 5 teeth would be reasonable. According to Loguercio et al. [30] intratooth variability is higher than intertooth variability. Therefore, to reduce the variability, since sticks from the same tooth cannot be considered as an experimental unit 
[30], microtensile bond strength was calculated for sticks produced from different teeth in this study.

All adhesive systems used in this study are one-step self-etching adhesive materials containing various different monomers and solvents. Some researchers reported that HEMA is an adhesion-promoting monomer due to its low viscosity and high hydrophilicity.[31,32]. HEMA assists 10-MDP and Bis-GMA monomers to enter the demineralized dentin and helps these monomers to form a durable bond strength .[33] All the adhesives in the present study contain HEMA as a common monomer. Furthermore, with HEMA, according to Goracci et al. [34] microtensile bond strength decreased when the specimen thickness increased, as had already been noted in some previous research. According to earlier reports [35-38], since internal defects induce stress generation, smaller specimens produce higher bond strength as they have fewer internal defects allowing a more homogenous stress distribution during microtensile testing. In the present study, the dimension of the specimens was 3 $\mathrm{mm} \times 3 \mathrm{~mm}$. Therefore, lower $\mu$ TBS values have been reported for adhesive systems obtained in the present study after nine months water storage, possibly because of the specimens' large dimensions. Furthermore, static water storage is a common procedure to prevent degradation in bonding mechanisms during in vitro research, although it is a time demanding strategy $[2,21]$. Moreover, literature about microtensile bond strength between adhesive material and dentin is limited and does not include long periods of water storage. Therefore, nine months of water storage was used to age the specimens in this study.

Nova Compo B Plus (NCBP) is a novel adhesive system containing 10-MDP and 4-META as monomers and it is also ethanol based. In the present study, NCBP showed the highest bond strength in superficial dentin surfaces but the lowest in deep dentin. NCBP is described by the manufacturer as a highly hydrophilic material before curing and during application for optimum wetting of the tooth structure. Thus, high hydrophilicity of this system may result in increased $\mu$ TBS in superficial dentin layers. Nevertheless, 4-META and 10-MDP are highly acidic monomers which are able to create strong ionic bonds with dentin's calcium content. Since the mineral content decreases with the increased dentin depth, the ionic bond formation of monomers with calcium increase [33], which could explain the reduced bond strength of NCBP in deep dentin surfaces obtained in the current study. Therefore, it could be stated that although the hydrophilicity of NCBP is important in superficial dentin, the acidic monomer composition of NCBP is a critical factor for $\mu$ TBS in deep dentin layers.

Nova Compo B (NCB) is an adhesive system containing GPDMA and 4-META hydrophobic monomers. NCB showed the lowest bond strength in superficial dentin surfaces, while the highest in deep dentin surfaces. In deep dentin surfaces, it was found that glycerol dimethacrylate (GDMA) priming could compensate for the disadvantage of lower calcium content in deep dentin surfaces. [39] In contrast to NCBP, NCB showed the highest $\mu$ TBS in deep dentin surfaces. Since NCB includes a glycerol phosphate dimethacrylate (GPDMA) monomer which has low viscosity and water solubility [40], it can be speculated that the phosphate group in the bonding agent plays an important role between dentin and resin materials, as was also reported by Asmussen and Munksgaard [41]. Nevertheless, NCB showed lower $\mu$ TBS in superficial dentin surfaces when compared to deep dentin. The possible reason for reduced bond strength could be that the phosphate monomer of NCB in hydrophilic superficial dentin might be prevent oxygen diffusion, resulting in incomplete polymerization in superficial dentin.

It has been known that ethanol is less volatile than acetone and helps to provide a stable consistent viscosity. Ethanol-based adhesive systems have higher viscosity than acetone-based adhesive systems. Furthermore, the decreased viscosity of adhesive resin in deep 
dentin layers inhibits polymerization by oxygen $[33,42]$. Futurabond $\mathrm{M}$ is a one-step self-etching adhesive containing HEMA, acidic monomers and organic acid and acetone [33]. Therefore, a possible explanation of decreased bond strength is that increased acetone content might result in thinner adhesive layer in deeper dentin sites. [43] Another possible explanation of decreased bond strength might result from intrinsic wetness of dentin, since the deep dentin layer is more wet than the superficial dentin [33]. Moreover, residual water and acetone content should be carefully removed from the deep dentin channels before resin polymerization. The application time for Futurabond M could be insufficient to remove the residual water and acetone. This could also another reason for the low $\mu$ TBS values. Furthermore, due to its low $\mathrm{pH}$, Futurabond M might show lower $\mu \mathrm{TBS}$ values in deep dentin layers than superficial dentin.

Because NCBP have more acidic monomers like 10-MDP and META, it may result in decreased $\mu$ TBS in deep dentin layers by forming strong bonds with dentin's mineral content. MDP has been rated as the most favorable monomer in dentin structure by forming strong chemical bonds with the calcium content of the tooth compared with the carboxylic-acid monomer 4-META $[44,45]$. The unique chemical structure of 10-MDP has been proven to play a key role in both the initial bonding performance as well as the durability of the adhesive interface. Yoshihara et al $[46,47]$ reported that self-etch adhesive systems containing 10-MDP produce long-term clinical results by creating nano-layer at the adhesive-dentin interface [48-50].

Clearfil S3 Bond Plus contains monomers and hydrophobic acrylate, all dissolved in ethanol. Its hydrophobic characteristics as high viscosity levels may reduce the inhibition of polymerization, which would result in higher $\mu$ TBS in both superficial and deep dentin layers [51]. In the present study, the results obtained for both superficial and deep dentin layers are relative for CS3. 10-MDP exists as a functional acidic monomer in NCBP and CS3 systems.
Moreover, two acidic monomer combination which are 10-MDP and 4-META could make NCBP more acidic material than CS3 which contains only one acidic monomer as 10-MDP. Thus, MDP allows CS3 to demonstrate similar bond strengths in both superficial and deep dentin layers as opposed to NCBP which is more acidic material. Given the results of this study, it could be stated that MDP solely is efficient by itself in the bonding mechanisms for both superficial and deep dentinal structures, while MDP and 4-META combination is efficient only in superficial dentin.

One of the limitations of this study is that the remaining dentin thicknesses were not measured by using a digital caliper or a microscope. The measurements were done by the researchers by using a manual caliper and the remaining dentin thickness which was below $2 \mathrm{~mm}$ was categorized as deep dentin according to Inoue et al [52]. Therefore, the exact measurements could be made by using a digital device and the accurate results could be drawn thereafter.

\section{CONCLUSION}

Given the results of this study the following conclusions may be drawn: The null hypothesis was that different adhesive systems containing different monomers and dentin thickness would not affect microtensile bond strength between resin composite and dentin after long-term water storage.

1. The experimental hypothesis was rejected in the present study. Adhesive systems used in the present study have different effects on the microtensile test results of dentin specimens after 9-months water storage. In this regard, the 4-META and 10-MDP monomer combination resulted in the highest bond strength value of all the adhesive systems in the superficial dentin group. Moreover, the GPDMA and 4-META monomer combination resulted in the highest bond strength in deep dentin surfaces. It could be stated that a glycerol phosphate dimethacrylate (GPDMA) monomer might have positive effect 
on adhesion in deeper dentin surface while 10MDP in superficial dentin surface;

2. Bonding to different regions of the tooth might be affected by different functional monomers, methacrylate monomers, solvents, $\mathrm{pH}$ of the adhesive systems along with the dentin thickness.

\section{Conflict of interest}

The authors state that they have no conflicts of interest.

\section{REFERENCES}

1. Pashley $\mathrm{DH}$, Carvalho RM. Dentine permeability and dentine adhesion. JDent. 1997;25:355-72. doi: 10.1016/s0300-5712(96)00057-7.

2. Matsui N, Takagaki T, Sadr A, Ikeda M, Ichinose S, Nikaido T, Tagami J. The role of MDP in a bonding resin of a two-step self-etching adhesive system. Dent Mater J.2015;34:227-33. doi:10.4012/dmi.2014-205.

3. Nakabayashi N, Kojima K, Masuhara E. The promotion of adhesion by the infiltration of monomers into tooth substrates. J Biomed Mater Res. 1982;16:265-73. doi:101002/jbm.820160307.

4. Nakabayashi N, Nakamura M, Yasuda M. Hybrid layer as a dentin-bonding mechanism. JEsthet Dent. 1991;3:133-38. doi:10.1111/1.1708-8240.1991. tb00985.x.

5. Takahashi M, Nakajima M, Hosaka K, Ikeda M, Foxton RM, Tagami J. Longterm evaluation of water sorption and ultimate tensile strength of HEMAcontaining/-free one-step self-etch adhesives. J Dent. 2011;39:506-12. doi: 10.1016/j.jdent.2011.04.008.

6. Dhanpal P, Yiu CK, King NM, Tay FR, Hiraishi N. Effect of temperature on water sorption and solubility of dental adhesive resins. J Dent. 2009;37:122-32. doi: 10.1016/j.jdent.2008.10.004

7. Reis AF,Giannini M, Pereira PN. Influence of water-storage time on the sorption and solubility behavior of current adhesives and primer/adhesive mixtures. Oper Dent. 2007;32:53-9. doi:10.2341/06-13.

8. Hosaka K, Tagami J, Nishitani Y, YoshiyamaM, Carrilho M, TayFR, etal. Effect of wet vs. dry testing on the mechanical properties of hydrophilic self-etching primer polymers. Eur J Oral Sci. 2007;115:239-45. doi:10.1111/j.16000722.2007.00452x

9. Hosaka K, Nakajima M, Takahashi M, Itoh S, Ikeda M, Tagami J, Pashley DH. Relationship between mechanical properties of one-step self etch adhesives and water sorption. Dent Mater. 2010;26:360-7. doi: 10.1016/j.dental.2009.12.007.

10. Ito S, Hashimoto M, Wadgaonkar B, Svizero N, Carvalho R, Yiu C, et al. Effects of resin hydrophilicity on water sorption and changes in modulus of elasticity. Biomaterials. 2005;26:6449-59. doi:10.1016/j.biomaterials.2005.04.052

11. Paul SJ, Leach M, Rueggeberg FA, Pashley DH. Effect of water content on the physical properties of model dentine primer and bonding resins. J Dent. 1999;27:209-14. doi:101016/s0300-5712(98)00042-6.

12. Tay FR, Pashley DH, Yoshiyama M. Two modes of nanoleakage expression in single-step adhesives. JDentRes. 2002;81:472-6. doi: $10.1177 / 154405910208100708$

13. Spencer $P$, Wang Y.Adhesive phase separation at the dentin interface under wet bonding conditions. JBiomed Mater Res. 2002;62:447-456. doi:101002/ jbm.10364.
14. Ye Q, Park JG, Topp E, Wang Y, Misra A, Spencer P.In vitro performance of nano-heterogeneous dentin adhesive. JDent Res. 2008;87(9):829-833. doi:101177/154405910808700911.

15. YeQ, Wang Y,Spencer P.Nanophase separation of polymers exposed to simulated bonding conditions. J Biomed Mater Res B Appl Biomater. 2009;88(2):339-348. doi:10.1002/jbm.b.31047

16. Hashimoto M, Fujita S, Kaga M, Yawaka Y. In vitro durability of one-bottle resin adhesives bonded to dentin. Dent Mater J.2007;26:677-86. doi:10.4012/ dmj.26.677.

17. Torkabadi S, Nakajima M, Ikeda M, Foxton RM, Tagami J. Bonding durability of HEMA-free and HEMA-containing one-step adhesives to dentine surronded by bonded enamel.J Dent. 2008;36:80-6. doi:10.1016/j.jdent.2007.11.001.

18. Fukegawa D, Hayakawa S, Yoshida Y,SuzukiK, Osaka A, Van Meerbeek B. Chemical interaction of phosphoric acid ester with hydroxyapatite. J Dent Res. 2006;85(10):941-944. doi:10.1177/154405910608501014.

19. Yoshida Y, Van Meerbeek B, Nakayama Y, Snauwaert J, Hellemans L, Lambrechts P,et al. Evidence of chemical bonding at biomaterialhard tissue interfaces. JDent Res. 2000;79(2):709-714. doi: 10.1177/00220345000790020301.

20. Foxton RM, Melo L, Stone DG, Pilecki P,Sherriff M, Watson TF.Long-term durability of one-step adhesive-composite systems to enamel and dentin. Oper Dent. 2008;33(6):651-7. doi:10.2341/07-166.

21. De Munck J, Van LanduytK, Peumans M, Poitevin A, Lambrechts P, Braem M, Van Meerbeek B. A critical review of the durability of adhesion to tooth tissue: methods and results. J Dent Res. 2005;84:118-32. doi: 10.1177/154405910508400204

22. Pashley EL, Agee KA, Pashley DH, Tay FR. Effects of one versus two applications of an unfilled, all-in-one adhesive on dentine bonding. J Dent. 2002;30:83-90. doi: 10.1016/s0300-5712(02)00002-7.

23. Tay FR, Pashley DH, Suh BI, Carvalho RM, Itthagarun A. Single-step adhesives are permeable membranes. J Dent. 2002;30:371-82. doi:10.1016/s03005712(02)00064-7.

24. Itoh S, Nakajima M, Hosaka K, Okuma M, Takahashi M, Shinoda Y, etal. Dentin bond durability and water sorption/solubility of one-step self-etch adhesives. Dent Mater J. 2010;29:623-30. doi: 10.4012/dmj.2010-028.

25. Pereira PN, Okuda M, Sano H, Yoshikawa T, Burrow MF, Tagami J. Effect of intrinsic wetness and regional difference on dentin bond strength. Dent Mater. 1999:15:46-53. doi: 10.1016/s0109-5641(99)00013-5.

26. Van Landuyt KL, De Munck J, Snauwert J, Coutinho E, Poitevin A, Yoshida Y, et al. Monomer-solvent phase separation in one-step self-etch adhesives. JDent Res. 2005;84:183-8. doi: 10.1177/154405910508400214.

27. Roulet JF, Van Meerbeek B. Editorial:Statistics: a nuisance, a tool, or a must? J Adhes Dent. 2007:9:287-8. doi:10.3290/j.jad.a29842

28. Miranda TA, Moura SK, Amorim VH, Terada RS, Pascotto RC. Influence of exposure time to saliva and antioxidant treatment on bond strength to enamel after tooth bleaching: an in situ study. J Appl Oral Sci. 2013;21:567-74. doi: 10.1590/1679-775720130035.

29. Van Meerbeek B, Peumans M, Poitevin A, Mine A, Van Ende A, Neves A, De Munck J. Relationship between bond-strength tests and clinical outcomes. Dent Mater .2010;26:100-21. doi:10.1016/j.dental.2009.11.148.

30. Loguercio AD, Barroso LP, Grande RH, Reis A. Comparison of intra- and intertooth resin-dentin bond strength variability. J Adhes Dent. 2005;7:151-158

31. Nakaoki Y, Nikaido T, Pereira PN, Inokoshi S, Tagami J. Dimensional changes of demineralized dentin treated with HEMA primers. Dent Mater. 2000;16:441-6. doi: 10.1016/s0109-5641(00)00042-7. 
32. Van LanduytKL, Snauwaert J, De Munck J,Peumans M, Yoshida Y, Poitevin A, etal. Systematic review of the chemical composition of contemporary dental adhesives. Biomaterials. 2007;28:3757-85. doi:10.1016/j. biomaterials.2007.04.044.

33. Ting S, Chowdhury AA, Pan F,Fu J, Sun J, Kakuda S, etal. Effect of remaining dentin thickness on microtensile bond strength of current adhesive systems. Dent Mater J. 2015;34:181-8. doi: 10.4012/dmj.2014-130.

34. Goracci C, Sadek FT,Monticelli F,Cardoso PE,Ferrari M. Influence of substrate, shape, and thickness on microtensile specimens' structural integrity and their measured bond strengths. Dent Mater.2004;20:643-54. do: 10.1016/j. dental.2003.08.009.

35. Sano H, Shono T, Sonoda H, Pashley DH. Relationship between surface area for adhesion and tensile bond strength-evaluation of a microtensile test. Dent Mater. 1994;10:236-40. doi: 10.1016/0109-5641(94)90067-1.

36. Pashley DH, Ciucchi B, Sano H, Yoshiyama M, Carvalho RM. Adhesion testing of dentin bonding agents. A review. Dent Mater. 1995;11:117-25. doi: 10.1016/01095641(95)80046-8.

37. Phrukkanon S, Burrow MF, Tyas MJ. The influence of crosssectional shape and surface area on the microtensile bond test. Dent Mater. 1998;14:212-221. doi: 10.1016/s0109-5641(98)00034-7.

38. Pashley DH, Carvalho RM, Sano H, Nakajima M, Yoshiyama M, Shono Y, etal.. The microtensile bond test: a review. J Adhes Dent 1999;1:299-309.

39. Chigira H, Itoh K, Tachikawa T, Wakumoto S, Hisamitsu H. Bonding efficacy and interfacial microstructure between resin and dentine primed with glyceryl methacrylate.J Jent. 1998;26:157-63. doi:10.1016/50300-5712(96)00085-1.

40. Koliniotou-KoumpiaE, Kouros P,Koumpia E, Helvatzoglou-Antoniades M. Shear bond strength of a "solvent-free" adhesive versus contemporary adhesive systems. Braz J Oral Sci. 2014;13:64-9.Doi: 101590/1677-3225v13n1a13

41. AsmussenE, Munksgaard EC. Bonding of restorative resins to dentine: status of dentine adhesives and impact on cavity design and filling techniques. Int DentJ. 1988;38:97-104.

42. Sakano W, Nakajima M, Prasansuttiporn T,Foxton RM, Tagami J. Polymerization behavior within adhesive layer of one-and two-step self-etch adhesives: a micro-Raman spectroscopic study.Dent Mater J. 2013;32:992-8. doi:10.4012/dmj.2013-095.
43. Tekce N, Demirci M, Tuncer S, Uysal Ö. Microtensile bond strength and sealing efficiency of all-in-one self-etching adhesives. Biotechnol Biotechnol Equip. 2015;29:570-8.Doi:https://doi.org/10.1080/13102818.2015.1008875.

44. Yoshida Y,Nagakane K, Fukuda R, Nakayama Y, Okazaki M, Shintani H, etal. Comparative study on adhesive performance of functional monomers. J Dent Res. 2004;83:454-8. doi: 10.1177/154405910408300604.

45. Yoshihara K, Yoshida Y,Nagaoka N, Fukegawa D, Hayakawa S, Mine A, et al. Nano-controlled molecular interaction at adhesive interfaces for hard tissue reconstruction. Acta Biomater.2010;6:3573-82. doi: 10.1016/j. actbio.2010.03.024.

46. Yoshihara K, Yoshida Y, Hayakawa S, Nagaoka N, Irie M, Ogawa T,etal. Nanolayering of phosphoric acid ester monomer on enamel and dentin. Acta Biomater.2011;7:3187-95. doi:10.1016/j.actbio.2011.04.026.

47. Yoshihara K, Yoshida Y, Hayakawa S, Nagaoka N, Torii Y,Osaka A, etal. Selfetch monomer-calcium salt deposition on dentin. J Dent Res. 2011;90:602-606. doi:10.1177/0022034510397197.

48. Peumans M, De Munck J, Van Landuyt KL, Poitevin A, Lambrechts P, Van Meerbeek B. Eight-year clinical evaluation of a 2-step self-etch adhesive with and without selective enamel etching. Dent Mater. 2010;26:1176-84. doi: 10.1016/j.dental.2010.08.190

49. Van Meerbeek B, Yoshihara K, Yoshida Y,Mine A, De Munck J, Van LanduytK State of the art of self-etch adhesives. Dent Mater. 2011;27:17-28. doi: 10.1016/j. dental.2010.10.023.

50. Feitosa VP, Ogliari FA, Van Meerbeek B, Watson TF, Yoshihara K, Ogliari A0, etal. Can the hydrophilicity of functional monomers affect chemical interaction? J Dent Res. 2014;93:201-6. doi: 10.1177/0022034513514587.

51. Gauthier MA, Stangel I,Ellis TH,Zhu XX. Oxygen inhibition in dental resins. J DentRes. 2005;84:725-9. doi: 10.1177/154405910508400808.

52. Inoue S, Van Meerbeek B, Abe Y, Yoshida Y, Lambrechts P, Vanherle G, et al. Effect of remaining dentin thickness and the use of conditioner on micro-tensile bond strength of a glass-ionomer adhesive. Dent Mater. 2001;:17(5):445-455. doi:10.1016/s0109-5641(01)00003-3.

\section{Dr. Pinar Cevik, Gazi}

(Corresponding address)

University Faculty of Dentistry Department of Prosthodontics, Biskek Cd, 82.

Sokak, No:4, Emek, 06510, Ankara, Turkey.

Date submitted: 2020 Feb 27

E-mail: dt_pinarcevik@yahoo.com 